\title{
The impact of Corporate Social Responsibility on brand loyalty in the process of globalization
}

\author{
Margareta Nadanyiova ${ }^{1, *}$, Lubica Gajanova ${ }^{1}$ \\ ${ }^{1}$ University of Zilina, Faculty of Operation and Economics of Transport and Communications, \\ Department of Economics, Univerzitna 8215/1, 01026 Zilina, Slovak Republic
}

\begin{abstract}
In the process of globalization, the topic of sustainable development is among the most up-to-date and discussed issues. Companies applying the principles of social responsibility are focused not only on profit, but above all on sustainable growth and development. And just the triple bottom line concept represents a tool that enables CSR put into practice and points out that economic interests may not be in conflict with social and environmental issues. The aim of this article includes providing a literature review on the issue from the perspective of several foreign and domestic authors. By using methods of description, comparison, deduction, induction, it discusses the essence of corporate social responsibility, the concept of triple bottom line and also analyses its practical use in the case of the particular company. The secondary data for the analysis were obtained from annual company reports, statistical tables and published professional publications. In order to determine the impact of corporate social responsibility on brand loyalty in the process of globalization, a questionnaire survey was conducted among Slovak consumers. General scientific methods were applied for the processing of the data, as well as mathematical methods to evaluate the data collated from the results of the questionnaire survey. Based on this, benefits of using CSR principles are highlighted, that includes, in particular, building customer relationships, increasing the brand value and gaining brand loyalty. Finally, proposals are put forward for the effective implementation of corporate social responsibility principles in the process of globalization.
\end{abstract}

\section{Introduction}

Increasing globalization has made the concept of corporate social responsibility a positive trend when companies focus not only on profit but above all on sustainable growth and development. Since the end of the 20th century, the European Union has fully committed itself to promoting responsible corporate behaviour in its member states and encouraging them not to forget the key challenges affecting consumer interests, human rights and the elimination of adverse effects. Many companies, especially under the influence of stakeholders, are beginning to apply the principles and values of the concept in everyday business practice $[1,2]$. Ethical behaviour and the importance of its position are essential because the current customer is unwilling to undergo unethical behaviour and favours

* Corresponding author: margareta.nadanyiova@fpedas.uniza.sk 
socially responsible companies [3]. Currently, social responsibility is a positive tendency $[4,5]$. Despite the fact that the number of socially responsible companies in Slovakia is relatively low, it has an increasing character. Companies are aware of their negative impact on the environment and seek to eliminate it through the principles of corporate social responsibility, thereby increasing their competitiveness, image and customer loyalty $[6,7]$.

The aim of this article includes providing a literature review on the issue from the perspective of several foreign and domestic authors. By using methods of description, comparison, deduction, induction, it discusses the essence of corporate social responsibility, the concept of triple bottom line and also analyses its practical use in the case of the particular company. The secondary data for the analysis were obtained from annual company reports, statistical tables and published professional publications. In order to determine the impact of corporate social responsibility on brand loyalty in the process of globalization, a questionnaire survey was conducted among Slovak consumers. General scientific methods were applied for the processing of the data, as well as mathematical methods to evaluate the data collated from the results of the questionnaire survey. Based on this, benefits of using CSR principles are highlighted, that includes, in particular, building customer relationships, increasing the brand value and gaining brand loyalty. Finally, proposals are put forward for the effective implementation of corporate social responsibility principles in the process of globalization.

\section{Literature Review}

The issue of the CSR has been researched and analysed by many foreign and domestic authors, and remains actual.

The concept of CSR was first defined by Bowen as the obligations of businessmen to pursue those policies, to make those decisions, or to follow those lines of action which are desirable in terms of the objectives and values of our society [8]. CSR means to use its resources and engage in activities designed to increase its profits so long as it stays within the rules of the game, which is to say, engages in open and free competition without deception or fraud [9]. Davis defines CSR as the firm's consideration of and response to, issues beyond the narrow economic, technical, and legal requirements of the firm to accomplish social benefits along with the traditional economic gains which the firm seeks [10]. According to Carroll, the social responsibility of business encompasses the economic, legal, ethical and discretionary expectations that society has of organisations at a given point in time [11]. Burke and Logsdon identified five dimensions of strategic CSR which, for them, are essential for achieving the business objectives as well as for value creation: centrality, specificity, proactivity, visibility, and voluntarism [12]. These five strategic CSR dimensions help to explain how resources and capabilities may create value for the firm. Smith pointed out that CSR relates to the company's obligations to its stakeholders and is influenced by corporate policies and practices [13]. These obligations go beyond the statutory requirements and obligations of the company towards shareholders. The purpose of meeting these obligations is to minimize any damage and maximize the long-term positive impact of the company on the company. A similar view was presented by Bussard et al., according to which CSR represents a set of management practices of the company that minimize the negative and at the same time maximize the positive consequences of its behaviour on the company [14]. Steinerova and Makowski argue that the concept of CSR is a way of doing business and building relationships that contribute to improving the reputation and credibility of society [15]. CSR can also be seen as a voluntary integration of social and environmental aspects into the company's daily business operations and interaction with stakeholders [16]. Based on several previous definitions, Dahlsrud has 
defined five basic aspects of CSR that have been repeated in these definitions, namely environmental fields, social fields, economic fields, stakeholders and volunteering [17].

As is apparent from the above, the main features of the CSR are the principle of volunteering, which is mentioned in several other definitions not only at the academic level, but also from the perspective of different organizations:

- CSR represents the commitment of business to contribute to sustainable economic development, working with employees, their families, the local community, and society at large to improve their quality of life [18].

- CSR includes operating a business in a manner that meets or exceeds the ethical, legal, commercial and public expectations that society has of business [19].

- CSR is a concept whereby the company integrates social and environmental concerns in their business operations and in their interactions with their stakeholders on a voluntary basis [20].

- CSR is the way in which a company manages and improves its social and environmental impact to generate value for both its shareholders and its stakeholders by innovating its strategy, organization and operations [21].

- CSR is the responsibility of enterprises for their impacts on society. Respect for applicable legislation, and for collective agreements between social partners, is a prerequisite for meeting that responsibility. To fully meet their corporate social responsibility, enterprises should have in place a process to integrate social, environmental, ethical, human rights and consumer concerns into their business operations and core strategy in close collaboration with their stakeholders [22].

Over the years, many authors have dealt with the issue how CSR affects brand as well as brand loyalty. Poolthong and Mandhachitara explore how social responsibility initiatives can influence perceived service quality and brand effect [23]. Polonsky and Jevons develop the sub-issues of issue, organizational and communication complexity associated with global brands' CSR activities [24]. They found out that within these three areas of complexity there are a number of sub-issues that must be addressed if CSR is to be strategically integrated into a global brand. Hur et al. investigate the relationships among CSR, brand credibility, brand value and corporate reputation [25]. Cha et al. examine how customer participation in a firm's CSR activities strengthens the formation of service brand loyalty [26]. Martinez et al. investigate the influence of CSR on brand image and loyalty in the hotel industry [27]. Moon et al. focused their research on the investigation the relationship between consumers' corporate associations, consumer-corporate connection, and corporate brand loyalty, with a particular focus on the moderating role of national culture [28]. Pratihari and Uzma aim to examine the effect of CSR on corporate branding and brand loyalty in the banking industry. The results of their study show that there is a significant impact of CSR components on corporate branding to enhance customer brand loyalty [29]. Moisescu and Gica deal with the moderating influence of consumer demographics on the relationship between customers' perceptions of CSR and their corporate brand loyalty toward retails banks. They found out several significant dissimilarities between gender, age, education and residence type-based consumer segments in what concerns the impact of various CSR dimensions, as perceived by customers, on brand loyalty towards corporate brands in the banking sector [30].

Most approaches to the concept of CSR are closely linked to the issue of sustainable development, both of which are based on the Triple Bottom Line concept (TBL) by Elkington, founder of a British consulting firm called Sustainability. The essence of the TBL concept includes the three pillars of CSR as part of the company's business. Originally, this theory contained only one pillar focused on the environmental aspect, later supplemented by a socio-economic aspect, up to the three-pillar concept - environmental, economic and social. In 1995, British consultancy Sustainability reformulated Elkington's 
three-pillar idea for the more widespread end of 3P - People, Planet and Profit, which is actually an expression of the company's social, environmental and economic responsibility [31]. The economic bottom line is focused on tracking and improving the key business processes, by which the company contributes to the development of the economic environment with an effort to minimize negative consequences of business in this area. It includes corporate ethics code, responsible approach and customer care, provision of transparent information, corruption rejection, intellectual property protection, offer of quality products and services, product innovation and sustainability, good customer relations and good investor relations [32]. The environmental bottom line contains both internal and external activities. Internal environmental activities include company's environmental policy, implementation of environmental management systems, waste management, transport, purchasing, conservation of natural resources, training programs for environmental management staff. As the most frequently used external environmental programs we consider the environmental protection programs, environmental education programs for teachers, creating formal relationships with environmental groups in the field of the environment, building partnerships with non-profit organizations and local authorities in addressing major environmental problems, organizing annual meetings between the organization and local environmental officials, publishing environmental reports, informing the public about the company's environmental activities, philanthropic support for environmental activities [33]. The social bottom line includes health care, employee safety and quality employment policy, care for education, retraining, equal opportunities for everybody, corporate philanthropy and volunteering, child labour rejection, respect for human rights, work-life balance, and internal communication [32]. A socially responsible company should be active in all three areas in specific activities depending on the business focus and the requirements of other stakeholders. In summary, the triple bottom line measures level of social responsibility in the company, its economic value as well as environmental impact.

\section{Methods}

The aim of this article includes providing a literature review on the issue from the perspective of several foreign and domestic authors. By using methods of description, comparison, deduction, induction, it discusses the essence of corporate social responsibility, the concept of triple bottom line and also analyses its practical use in the case of the particular company. The secondary data for the analysis were obtained from annual company reports, statistical tables and published professional publications. In order to determine the impact of corporate social responsibility on brand loyalty in the process of globalization, a questionnaire survey was conducted among Slovak consumers. Based on this, benefits of using CSR principles are highlighted, that includes, in particular, building customer relationships, increasing the brand value and gaining brand loyalty. Finally, proposals are put forward for the effective implementation of corporate social responsibility principles in the process of globalization.

The secondary data for the analysis were obtained from annual company reports, statistical tables and published professional publications - both in print and electronic media. In order to determine the impact of CSR on brand loyalty from the viewpoint of Slovak consumers, a questionnaire survey was provided. General scientific methods were applied for the processing of the data, as well as mathematical methods to evaluate the data collated from the results of the questionnaire survey. When examining and identifying the utilization of the principles of CSR, the definitions of the approaches and concepts that are mentioned above were maintained. 
The aim of the questionnaire survey - both electronic and personal - was to analyse the application of the principles of corporate social responsibility in the particular company from the consumer's perspective, as well as to identify to determine the impact of CSR on brand loyalty. The sample size was determined using the Sample Size Calculator that forms part of Creative Research Systems' survey software and which is provided as a public service. The calculator determines how many respondents need to be interviewed in order to get results that reflect the target population as precisely as possible. This is necessary to avoid any distortion in the survey information. The process requires a base file to work from, which in this case consisted of population data for the city of Zilina, who are potential customers of the selected company, and in particular data on those aged 18 and above, i.e. 125,583 people. The age limit of 18 years was selected because this is considered the age at which people become financially independent. The confidence interval was set at $5 \%$, with a confidence level of $95 \%$. This means that for the questionnaire survey a $5 \%$ margin of error is assumed. The sample size calculated by the calculator was determined to be 383 respondents. In total, 402 respondents participated in the questionnaire survey. The questionnaire survey was conducted during the first half of the 2019. The selection of the respondents in the sample set took place at random and was based on the number of the city of Zilina habitants aged 18 years and above that represent the target groups of consumers. The quantitative assessment method was applied to the processing of the information obtained from the questionnaire survey. The data were processed empirically in the form of percentages, with additional written comments and comparisons.

\section{Results and discussion}

Application of CSR concept in specific conditions of the Slovak Republic is analysed in case of the particular company, which is Transport Enterprise of the city of Zilina (DPMZ Slovak abbreviation). The transport enterprise was established in 1949 under the name Communal Transport Company Zilina, and it started to provide bus services for the public in the city of Zilina in the same year. In the past, as the only one transport company in Slovakia, it also provided shipping. Since 1953 it has been called Transport Enterprise of the city of Zilina. At present, DPMZ operates urban public transport on its 8 trolleybus lines and 13 bus lines, including the night line. DPMZ currently has 268 employees, and its fleet consists of 42 trolleybuses and 40 buses. Passenger services provide 2 retail outlets and 44 vending machines, most of which are able to provide multiple types of tickets to the passenger. Since 1996, the company has been focusing on the gradual electrisation of public transport. As the first city in Slovakia, it had the information system in all vehicles, which consists of a trip computer, electronic marker, electronic road signs and acoustic alarms for notification stops in the vehicle interior and in the exterior for blind and visually impaired people needs. The data obtained through this information system allow to evaluate the transport, technical and economic criteria of public transport. They are also the basis for optimizing traffic. Company DPMZ has undergone changes in the organization with the necessity of the modernization of the fleet, electrisation of work and the provision of new services. DPMZ is one of the providers which provide transport also to KIA motors Slovakia factories in Teplicka nad Vahom. Another kind of business is coach transport. DPMZ also has coach buses by which it is able to offer customers comfortable international or domestic transport according to customers wishes. DPMZ runs two places of business which are $3.5 \mathrm{~km}$ away from each other: administration, trolleybus parking area and shops, bus parking area and pertinent shops. There are 2 sales points selling tickets and recharging smart cards in the downtown of Zilina as well as 44 ticket machines located at the bus stops all over the city. All of them provide tickets for more than one fare zone [34]. 
This transport enterprise seeks to engage in various activities for citizens' satisfaction and the development of Zilina. Its social responsibility activities have been assessed in three pillars - economic, environmental and social. The economic area is dynamic, constantly changing and mentioned indicators present the graduation, stagnation or degradation of key processes that give a picture of the potential benefits and development of the company. The most significant economic indicator is profit. DPMZ has a long-term negative economic result, but it still has a positive gradual tendency. One reason is the fact that it invests a lot in the purchase of new trolleybuses and new buses every year. The company is also partly subsidized by the city of Zilina each year. Each of the stakeholders is most interested about the financial effect and despite its negative result it has a favourable opinion on the approach to business management. For companies engaged in socially responsible business is not necessary to abandon their primary goal of generating profits and only devote themselves to charity. Other economic indicators also indicate that the company's costs still exceed revenues. Given that this company is subsidized by the city of Zilina, this economic indicator is irrelevant. The repairs and maintenance of the company are mainly related to the transport and service segment and have not changed significantly during the last 8 years, which is a good fact considering the fact that buses and trolleybuses are outdated, and they must be kept in perfect condition. An interesting indicator is energy consumption that has been declining. Achieving savings in sustainable resource management is one of the goals of a socially responsible company. Another of the economic and also environmental indicators is the company's fleet. All trolleybuses have been replaced with modern, with the reduced boarding platform, bigger and more efficient, they transport more people so they are more environmentally friendly. Buses have been replaced for low emission vehicles such as with hybrid drive. The transport of more passengers from lower consumption and reduced flue gas reduces the negative effects of the company's activities on the environment.

DPMZ as a company transporting daily a large number of passengers has to behave responsibly to the environment, not only by purchasing the most modern trolleybuses, reduced emission buses, but also by complying with the basic norms stipulated by the law of the Slovak Republic. The company has been involved in several major projects aimed at developing Zilina and meeting the needs of passengers. Collaboration with the University of Zilina and specialized high schools, such as the transport Academy in Zilina, has been developed. Every year, DPMZ organizes the "Open Doors Day in DPMZ". The company is also actively involved in the "World Day without Cars" event in the framework of the European Mobility Week campaign, in the form of a free urban public transport. Company has joined the Europe-wide campaign so called "European Mobility Week" to promote electric-powered transport where one of the campaign's part used to be also "The European Trolleybus Day". Since 2008, Zilina has become a partner of the international project "BENEFIT" - Progressive measures for an organization to intensify the use of public transport by its employees, together with the DPMZ and the University of Zilina. In the premises of DPMZ was also a ceremony of the "Skid School", with the initiative of the Regional Directorate of the Police Force in Zilina and the Zilina Self-Governing Region. The waste management of DPMZ is managed in accordance with the waste management requirements of the Slovak legislation. Process management is provided by the environmental reviewer of the company, overseeing the availability and compliance of legislation in the company, evaluating and proposing environmental objectives, and integrating them with the management into the waste management system of the company. DPMZ regulates relations between employees arising from the implementation of strategic and corporate tasks of the company by the code of ethics. A pleasant work environment and good communication with employees create a long-term relationship between the employer and employee. Employees are trained and motivated. Labour regulations, directives, 
regulations, standards of conduct and conduct, together with corporate culture and organizational rules of the company are governed by the applicable standards. Company uses personnel marketing tools, thanks what the human potential of the company is in accordance with its needs and creates versatile conditions and prerequisites for a high level of work performance, conduct and accountability governing these standards. Essential training courses include training following the requirements of legislation, in particular regard to training of drivers, operator of the gas filler, stokers, electricians for maintenance of buildings and equipment, operator of lifting equipment and operator of pressure equipment. The company has a draft training plan. All training courses in the company are based on valid legislation and standards. Health and safety at work are important for the social sphere. Employees of the company are repeatedly trained in occupational safety and awareness of legislation on OSH issues. On the basis of education, workers are acquainted with the wording of policies of health and safety at work, accidents at work, causes of occupational accidents and measures. Training also includes informing employees about possible threats and risks arising from the work and the operation of the equipment used. Other necessary professional training and education are provided by law and other staff regulations at prescribed intervals by persons with appropriate professional qualifications, such as training of drivers, referent vehicles, driving trucks, persons handling lifting equipment and so on.

As mentioned, in order to determine the impact of CSR on brand loyalty, a questionnaire survey was provided. The results of the questionnaire survey revealed that of the 402 respondents in the sample set, $69 \%$ were female and $31 \%$ male. $74.13 \%$ respondents belong to customers of DPMZ, $25.87 \%$ do not use services of the company. $49.33 \%$ respondents use DPMZ services regularly, 28.19\% several times a week and $22.48 \%$ occasionally. $24.38 \%$ respondents indicated the CSR involvement of DPMZ very positive, $41.04 \%$ have neutral feelings in this issue, $30.10 \%$ do not know the answer marked and $4.48 \%$ consider DPMZ involvement as very negative. Within the scope of DPMZ activities in the economic field, $23.63 \%$ respondents would welcome an increase in activity in identifying customer feedback, $23.38 \%$ improving service quality, $23.13 \%$ improving customer service, $21.64 \%$ increasing product awareness, $4.23 \%$ involvement of the customer in the decision-making process and 3.98\% would welcome a higher level of activity in improving the image of the company. $44.03 \%$ respondents consider the program of free and discounted travel of the DPMZ to be sufficiently socially oriented, $33.33 \%$ average socially oriented, $13.93 \%$ are extremely satisfied and $8.71 \%$ are insufficiently satisfied. Almost $50 \%$ respondents did not meet or participated in any projects of DPMZ; $25.12 \%$ respondents consider the European Mobility Week as the best-known activity, followed by Open Doors Day in DPMZ by $23.88 \%$ respondents and $5.72 \%$ respondents indicated the activity of the non-profit organization MULICA. 41.04\% respondents consider the responsibility of the company in the social field as neutral, $30.10 \%$ respondents cannot judge it and $24.38 \%$ respondents perceive it positively; only $4.48 \%$ respondents consider the DPMZ social responsibility very negative. The impact of CSR activities of DPMZ on consumer behaviour and their brand loyalty can be divided into two groups based on the survey conducted; $57.71 \%$ respondents said that it had a positive impact and will ultimately make more use of DPMZ services, $42.29 \%$ respondents say that it has no effect.

Based on the survey conducted on the application of the principles of CSR in DPMZ and its perception by Slovak consumers, it can be concluded that the activities of the company in the field of CSR are not indifferent to consumers. Raising awareness and awareness of the responsible attitude of the DPMZ carrier as well as other companies will help to eliminate doubts and mistrust by consumers. This will ultimately result in an 
increase in demand for services provided by companies and an increase in consumer loyalty to both the company and the brand.

In Slovakia, the concept of CSR is widely applied in large enterprises with foreign participation. For general public, this topic is still not well-known, which does not mean that companies are not responsible. Especially companies supporting community projects and charity have deep-rooted principles of social responsibility. Unfortunately, in many cases of Slovak companies, CSR activities are still limited only to philanthropy and charity. However, these principles are applied not only in multinational companies that have brought CSR to Slovakia from the parent company, but increasingly in domestic companies. The idea of CSR was emerged and developed mainly in countries with stable market economies. In Slovakia and other Central European countries, it is necessary to take into account the specific conditions of implementing CSR strategies. However, it is not always possible to use the same procedures as in developed countries. The sociologist Lewicka-Strzalecka, which deals with the issue of CSR, speaks about the phenomenon of rationality asymmetry when rational procedures are developed by the institution for a market with different characteristics and historical experience introduced in postcommunist countries. It is clear that if some of these countries try to implement effective solutions transferred from developed economies, this will not be successful, but on the contrary, poverty as well as social differences will increase. For that reason, the way of promoting and implementing CSR activities should be adapted to the country's specific conditions [35]. The Slovak Republic is characterized by its uniqueness, distinctive culture and history, and that is why the implementation of CSR is perceived differently than in other countries. In this case, the important factor is the level of economy advance and overall social system of the country. Many economically advanced countries demand corporate social responsibility by law, but this fact changes the essential of the CSR concept - voluntary approach. The main success factors of the CSR (not only in Slovakia) include its perception by consumers. Based on this, we recommend DPMZ to focus more on informing its customers and the general public about activities carried out in the field of social responsibility, as the level of their awareness is still insufficient.

\section{Conclusions}

One of the main benefits of implementing CSR in DPMZ is the creation of a positive corporate atmosphere. Creating a positive relationship and linking employees with the company creates their confidence in decision making, resulting in greater motivation and productivity. Company is becoming more attractive because they are in a better position on the labour market and are sought after by employers, which will also attract and retain quality employees in DPMZ.

The ability to reconcile the interests of the company with the stakeholders and good financial conditions, eliminate the potential risk of the company, thus making capital available and attracting more investors. The transparency and trust of the company will give investor confidence that their funds will be used efficiently. Another benefit concern improving the image, reputation and reputation of the public. The positive image of the DPMZ may have a greater positive impact on the overall existence of the company. Building a positive environmental relationship on which the CSR concept is based will help to build stakeholder confidence as well as brand loyalty that is important. If the DPMZ complies with the principles of corporate social responsibility, this will result in an increase in goodwill, a market position. At present, when the demands of the stakeholders are high, the company must build trust with the public, through social engagement and the implementation of these proposals. The benefit to a socially responsible business can be to gain a competitive advantage. The competitiveness of the company is the result of the level 
and influence of its business activities. CSR creates value for its customers that has special advantages and is unmatched.

This paper is an outcome of the science project APVV-15-0505: Integrated model of management support for building and managing the brand value in the specific conditions of the Slovak Republic.

\section{References}

1. K. Moravcikova, L. Stefanikova, M. Rypakova, CSR reporting as an important tool of CSR communication. In 4th World Conference on Business, Economics and Management (WCBEM) (Ephesus, Turkey, 332-338, 2015)

2. A. Krizanova, J. Majerova, K. Zvarikova, Green Marketing as a Tool of Achieving Competitive Advantage in Automotive Transport. In 17th International Conference on Transport Means (Kaunas, Lithuania, 45-48, 2013)

3. E. Stonkute, J. Vveinhardt, W. Sroka, Training the CSR Sensitive Mind-Set: The Integration of CSR into the Training of Business Administration Professionals. Sustainability, 10, 3, 754 (2018)

4. W. Sroka, R. Szanto, Corporate Social Responsibility and Business Ethics in Controversial Sectors: Analysis of Research Results. Journal of Entrepreneurship Management and Innovation, 14, 3, 111-126 (2018)

5. A. Krizanova, G. Masarova, L. Stefanikova, M. Rypakova, Building a Brand in the Context of Sustainable Development. In International Conference on Management Engineering and Management Innovation (ICMEMI) (Changsha, China, 79-84, 2015)

6. K. Valaskova, J. Kliestikova, J., A. Krizanova, Consumer Perception of Private Label Products: An Empirical Research. Journal of Competitiveness, 10, 149-163 (2018)

7. J. Kliestikova, M. Misankova, By disobedience to success: When brand value should be measured in a different way how the theory recommends. Economics and culture, 14, 33-43 (2017)

8. H. R. Bowen, Social Responsibilities of the Businessman (Iowa: University of Iowa Press, 1953)

9. M. Friedman, The social responsibility of business is to increase its profits. The New York Times Magazine, 32-33, 122-126 (1970).

10. K. Davis, The Case for and against Business Assumption of Social Responsibilities. Academy of Management Journal, 16, 312-322 (1973).

11. A. B. Carroll, A three-dimensional conceptual model of corporate performance. Academy of management review, 4, 497-505 (1979).

12. L. Burke, J. M. Logsdon, How corporate social responsibility pays off. Long Range Planning, 29, 495-502 (1996).

13. N. C. Smith, Changes in corporate practices in response to public interest advocacy and actions. Handbook of Marketing and Society, 140-161 (2001).

14. A. Bussard et al., Spoločensky zodpovedné podnikanie. Prehlad základných princípov a prikladov. (Bratislava: Nadácia Integra, 2005)

15. M. Steinerova, D. Makovski, Koncept CSR v praxi; průvodce zodpovědným podnikáním. (ASPRA a.s., 2008)

16. E. Chen, I. Gavious, Does CSR have Different Value Implications for Different Shareholders? Finance Research Letters, 14, 29-35 (2015). 
17. A. Dahlsrud, How Corporate Social Responsibility is defined: An Analysis of 37 Definitions. Corporate Social responsibility and Environmental Management, 15, 1-13 (2008).

18. WBCSD, Corporate social responsibility: Meeting changing expectations. (Geneva: World Business Council for Sustainable Development, 1999).

19. Business for Social Responsibility, Our Story. 2018. [Online]. Available at: https://www.bsr.org/en/about/story

20. European Commission, Green paper and related documents. [Online]. 2001. Available at: https://ec.europa.eu/environment/ipp /2001developments.htm

21. CSR Europe, Investing in responsible business: The 2003 survey of European fund managers, financial analysts and investor relations officers. (Brussels, Belgium: CSR Europe Publications, 2003)

22. European Commission, A Sustainable Europe by 2030. [Online]. 2019. Available at: https://ec.europa.eu/commission/publications/reflection-paper-towards-sustainableeurope-2030_sk

23. Y. Poolthong, R. Mandhachitara, Customer expectations of CSR, perceived service quality and brand effect in Thai retail banking, International Journal of Bank Marketing, 27, 408-427 (2009).

24. M. Polonsky, C. Jevons, Global branding and strategic CSR: an overview of three types of complexity. International Marketing Review, 26, 327-347 (2009).

25. W. M. Hur, How CSR Leads to Corporate Brand Equity: Mediating Mechanisms of Corporate Brand Credibility and Reputation, Journal of Business Ethics, 125, 75-86 (2014).

26. M. K. Cha, Y. Yi, R. P. Bagozzi, Effects of Customer Participation in Corporate Social Responsibility (CSR) Programs on the CSR-Brand Fit and Brand Loyalty. Cornell Hospitality Quarterly, 57, 235-249 (2016).

27. P. Martinez, A. Perez, I. R. Del Bosque, CSR influence on hotel brand image and loyalty. Academia-revista Latinoamericana de Administracion, 27, 267-283 (2014)

28. B. J. Moon, L. W. Lee, Ch. Oh, The impact of CSR on consumer-corporate connection and brand loyalty A cross cultural investigation. International Marketing Review, 32, 518-539 (2015)

29. S. K. Pratihari, S. H. Uzma, CSR and corporate branding effect on brand loyalty: a study on Indian banking industry. Journal of Product and Brand Management, 27, 57 78 (2018)

30. O. I. Moisescu, O. A. Gica, The moderating influence of consumer demographics on the relationship between perceived CSR and brand loyalty in the Romanian retail banking sector. E \& M Ekonomie a Management, 20, 187-202 (2017)

31. J. Elkington, Partnerships from cannibals with forks: The triple bottom line of 21 stcentury business. Environmental Quality Management, 8, 37-51 (1998).

32. M. Pavlik, M. Belcik, Společenská odpovědnost organizace. CSR v praxi a jak s ním dál. (Praha: Grada, 2010)

33. J. Zeleny, Environmental Management and Corporate Social Responsibility, (University of Matej Bel, Banska Bystrica, 2010)

34. DPMZ [Online]. 2019. Available at: ww.dpmz.sk

35. A. Lewicka-Strzalecka, Opportunities and Limitations of CSR in the Postcommunist Countries: Polish Case, Corporate Governance, 6, 440-448 (2006). 